\title{
On acts, omissions and responsibility
}

John Coggon

J. Med. Ethics 2008;34;576-579

doi:10.1136/jme.2008.024729

Updated information and services can be found at:

http://jme.bmj.com/cgi/content/full/34/8/576

These include:

References This article cites 6 articles, 4 of which can be accessed free at: http://jme.bmj.com/cgi/content/full/34/8/576\#BIBL

Rapid responses You can respond to this article at: http://jme.bmj.com/cgi/eletter-submit/34/8/576

Email alerting Receive free email alerts when new articles cite this article - sign up in the box at service the top right corner of the article

Notes

To order reprints of this article go to:

http://journals.bmj.com/cgi/reprintform

To subscribe to Journal of Medical Ethics go to:

http:/journals.bmj.com/subscriptions/ 


\section{On acts, omissions and responsibility}

\section{John Coggon}

This paper questions the relevance of distinguishing acts and omissions in moral argument. It responds to an article by McLachlan, published in this issue of the Journal of Medical Ethics (see page 636). I argue that McLachlan fails to establish that there is a moral difference between active and passive euthanasia and that he instead merely asserts that the difference exists. I suggest that McLachlan's paper relies on a false commitment to general rules that do not apply in every case. Furthermore, I question the lack of a moral framework provided in his argument. Finally, I briefly argue why some omissions may well be considered equivalent to some actions. I conclude that until McLachlan (or other commentators) demonstrates that it would be wrong, we should focus on agency and responsibility, rather than seek to derive normative conclusions from contrasts between active and passive causes.

In bioethical debates relating to euthanasia and associated end-of-life issues, commentators dispute the relevance of distinctions between so-called active and passive euthanasia. As a general means of assisting analysts in their studies of different practices, a taxonomy that distinguishes active and passive euthanasia can be useful, principally as we can not usefully argue about these matters unless we are clear about what our arguments touch upon. ${ }^{2}$ Although it seems to have become received wisdom from ethicists of quite conflicting views that moral propriety can not hang merely on whether a situation obtains because of (inter alia) an agent's action or inaction, there continue to be defences of the act/omission distinction. ${ }^{34}$ In his paper, ${ }^{1}$ McLachlan has attempted to add support to those who argue that the distinction between active and passive euthanasia is a moral one. Here I respond to McLachlan's paper, arguing that in it he fails to do more than assert that there is a moral difference. Furthermore, I contend that his arguments

Correspondence to: Dr J Coggon, Centre for Social Ethics and Policy and Institute for Science, Ethics and Innovation, School of Law, University of Manchester, Oxford Road, Manchester M13 9PL, UK; John.Coggon@ manchester.ac.uk and the analogies used to bolster them do more to confuse the situation than to clarify it. I suggest that the moral difference he claims to exist at best remains obscure and more probably is unreal. Either way, the conclusions advanced in his paper are not supported by the argument that precedes them. My argument develops through three stages. First, I question the tenability of McLachlan's claims by focusing on his failure to distinguish between general normative rules and specific moral questions to which they may apply. Second, I question the normativity on which McLachlan's claims might be based, arguing that his references to morality and moral rights and duties are not entrenched in any evident framework. Finally, I suggest that in normative moral discourse, ascertaining whether an event was caused by someone's act or omission is of no concern. Of concern are matters of agency and responsibility, not passive or active causation.

\section{A GENERAL POINT ABOUT GENERAL RULES AND SOME SPECIFIC POINTS ABOUT GENERAL AND SPECIFIC RULES}

There is a tension throughout McLachlan's paper, which is never addressed and which is problematic. Although his position seems to be modest-he does not argue that euthanasia, active or passive, may never be justifiedhe bases seeming absolute moral claims on general rules, which he then concedes may be broken in given circumstances. McLachlan does not seem concerned that the permissibility of breaking these rules destroys their absolute nature and thus leaves them entirely redundant as the basis for an absolute moral position. He posits the following, very strong obligation: "We are obliged to refrain from killing each and everyone." This sentence seems unambiguous. But its normative force is somewhat tempered by a claim that follows in the same section, where he tells us that killing may in fact be "morally right" and that it may be "morally more justifiable to kill someone than to let him die". This is confusing. It seems that we are morally obliged to refrain from killing, but that we can also be morally obliged to kill (or, at least, we are not morally obliged to refrain from doing it after all).

The only way to overcome this is to treat the principle "do not kill" as a general rule, but concede that it permits of exceptions. There are good reasons to work with general rules. When they are instilled, they may mean that people can act properly without having to stifle themselves with excessive deliberation all the time. For policy-makers, general rules are useful as a means of defining permissible conduct without having to allow for every nuance and complication of circumstance in a piece of legislation or other regulatory code. General rules can be good; but they are, of necessity, not absolutes. So, if McLachlan wishes to endorse the general rule that we must not kill anyone there is no problem, but there is a real and troubling problem if he bases an absolutist moral position on this general rule. Given that he explicitly allows for exceptions, there is no doubt that he does not consider it really to be an absolute rule.

There is an important connected point. McLachlan stresses the importance in understanding that there is a moral duty not to kill, but no corresponding duty to try to keep each and everyone alive. This seems to be based on the moral maxim "ought implies can". There is no way I can save, or prolong, everyone's life, but I can refrain from "actively" killing everyone. Therefore, on McLachlan's generalrule reasoning, only the latter is appropriate for becoming the subject of a moral duty; but we have seen that there are problems when we move from the general rule to the specific. With the killing/ letting die distinction posited by McLachlan, we see no way past this. I am writing this paper in my shared office in Manchester. Right now I am (passively?) exercising my duty not to kill. Yet my not killing of someone in Vienna is distinct from my not killing of someone in the same room. In the former, I am refraining from the impossible, in the latter I refrain from the possible. Although in both cases I fulfil my duty, it is only of moral interest (if at all) in relation to my refraining from the possible. Because he is stuck in the clash between general and specific rules, McLachlan does not give any account of why or how my omissions from the possible can not be morally important, or indistinct from actions within the possible. Surely it is important to 
distinguish in moral discourse omissions of the possible from other omissions, rather than treat them as being of the same genus simply because they both involve inaction. He concedes that there will be examples in which refraining from saving someone will be morally questionable, but does not say why these should not be considered equivalent to "actively killing" that person. If his position is based on a general rule, it may be of utility to policy-makers, but it is of no consequence to moral argumentation. McLachlan needs to speak to the specifics on terms that apply to them, not on terms based on a general rule. Highlighting the potential nature and extent of harmful omissions does not account for how we treat harmful omissions that an agent is able to remedy.

To support his arguments, McLachlan advances several somewhat mystifying examples. I will focus on three of them here. It seems that McLachlan thinks they speak universally; that they address all omissions. I doubt their normative force, the truth of some of their even speaking reasonably about omissions, and am entirely unpersuaded that they provide examples of universal moral truths regarding causation.

McLachlan's first example involves the non-restraint of a violent thug. He suggests that a person who ceases to restrain a thug can not be said to have killed a passer-by that the thug then murders. The conclusion that McLachlan invites us to draw from this is that switching off a ventilator will never kill anyone. This is perplexing. For one thing, it ignores the thug's own moral responsibilities, or implies that disease shares the thug's immoral character. McLachlan hides argument with the use of the word "directly". This unhelpful technique only serves to obscure begged questions. We are told that:

\begin{abstract}
"(A) ventilator might, in some instances, serve to counteract death. The switching off of a ventilator might, in a sense, be an indirect cause of death but it will not kill directly as, say, a heavy dose of some drugs will."
\end{abstract}

Whatever "directly" means here is unclear, but I suggest it is no more than a subset of the broader, unsubstantiated assertion that killing by withdrawing treatment is morally distinct from administering a lethal toxin. Why say the drugs directly cause death? It is not evident that we would be wrong to say that the drugs indirectly kill and that the direct cause of death is the patient's susceptibility to them. Either way, how releasing a thug equates with switching off a ventilator is beyond imagination. We are told that the thug murders. For the analogy to work, we need to accept that disease is-not figuratively but actually-a murderer. This is hard to believe; and it is harder still to accept that the thug analogy serves even as tentative proof that all acts are distinct from all omissions.

In his discussion of Princess Diana's death, McLachlan points to various causes that we may assume are real, but then tries to explain that these are not really real, or that his breakdown, if continued, would be infinite. An example to support this is the alleged "absence of sobriety on the part of the driver of her car". This is most odd. The specific omission, and the ones McLachlan uses to build up to it, could equally well be described as acts. If I get into trouble for being drunken, and try to explain away the (presumably "active" and apparent) presence of intoxication by saying that in fact what my castigator witnesses is a mere passivity - the absence of sobriety-I think my account would be contested. What is important, however, is this: whichever way it went, both descriptions work, and neither bears on the propriety of my drunkenness. It does not seem of import whether I'm refraining from being sober or actively being drunk.

The last of McLachlan's examples that I wish to consider relates to drowning children and the question of whether omissions kill them. This is a familiar example in discussions on acts and omissions. An agent witnesses a child drowning whom he could easily rescue. Does the agent kill the child by standing by and watching? McLachlan does not contend that there is no immorality in watching the death, but does suggest that it is a morally distinct thing to "active killing". His reasons remain obscure, however. $\mathrm{He}$ tells us that there is a significant moral difference, but gives no substantive moral argument in support. Instead, he attempts to draw from legal rights. There are three big flaws to this. First, the law is not the same everywhere, and there are jurisdictions in which citizens are obliged to rescue. There is no logical reason for the law to exclude "goodSamaritan duties", it is just that in some jurisdictions that has happened. ${ }^{5}$ Second, what is legal and what is moral by no means go hand in hand. This is why we see such an abundance of moral critiques of the law. It is weak to point to aspects of law (without more) to support a moral argument. Third, it does not draw from the crime of murder that many legal experts will be familiar with. McLachlan says:

"To fail to save a child is not (and should not be) to commit murder even if it sometimes is to be guilty of failing to fulfil a duty of care."

This applies, the argument holds, also to doctors' omissions. As a matter of fact, despite the general rule in English law that there are no legal duties to keep people alive, when a so-called "special relationship" exists, agents are responsible for the results of their acts and their omissions; ${ }^{6}$ and to be clear, killing by omission can be murder. ${ }^{7}$ The famous Bland case hung on this issue. ${ }^{8}$ The carers in that case were concerned that withdrawing Mr Bland's food and hydration would be murder and thus went to the courts for an answer. The House of Lords held that indeed it could be murder so long as the duty to treat remained. Although omissions were pivotal to the decision in the case, Mr Bland's carers escaped liability for murder not because of omissions simpliciter, but because of omissions combined with the evaporation of the duty to treat. McLachlan does not say which jurisdiction his claim relates to, but it is noteworthy that at least in some it is possible to murder by omission.

McLachlan builds on and draws from the examples presented in his piece, but claims such as the following are unhelpful and do not lead to sound philosophical conclusions:

\footnotetext{
"Sometimes, one could save one child from drowning only by neglecting some other drowning child. Contrariwise, it is not the case that one can avoid murdering one particular child only by murdering another one."
}

Considering derivations of cases such as the "trolley problem", 9 it is easily imaginable that philosophers could devise problems in which one might have to murder one child to save another one (or more). McLachlan's examples do little to present a moral distinction between acts and omissions.

\section{WHENCE THE MORALITY?}

There is a fundamental problem with the way that McLachlan's moral position is advanced. He gives no indication of what account of morality he is committed to. Perhaps, as his argument is said to 
relate to moral rights, he aims to speak against consequentialist theorists such as John Harris. ${ }^{10}$ If this is so, there is no immediately evident reason to believe he is correct in his assertions. Other analysts who shun consequentialist accounts find no special relevance to life-ending choices that allow people to kill by omission rather than act. ${ }^{11}$ Whatever the basis of McLachlan's moral assertions, this needs to be stipulated before analysts can justifiably be bound by them. If his paper iterates points that people already believe, this may provide some level of moral reassurance to them. Without a moral framework, however, it does not give anyone good reason to commit to it. Morality requires fundamental reasons, not simple assurances from philosophers that something is or is not morally this or that.

McLachlan pins much to "causal narratives". Reference to these seems initially to bear on empirical observations of the way we describe things. This is not intrinsically problematic, but it is a puzzle why it should have any bearing on morality. As I have already suggested, McLachlan seeks to impose his own "causal narrative" by deploying the word "directly", and thereby delimit the terms of moral causation and thus moral rights and duties. If morality turns on the "correct" narrative, we need to be shown why and we need to be shown how it is established. In his paper, I see no stronger basis for the moral claims than the fact that McLachlan is "uncomfortable about the bald claim that omissions can cause things to happen". This lack of comfort is not, of itself, a satisfactory basis on which to found moral rights.

\section{CAUSATION AND RESPONSIBILITY: IS MISSING THE POINT AN ACT OR AN OMISSION? (AND WHY THIS NEED NOT CONCERN US)}

McLachlan's paper involves much description of causation. It is unclear, however, why he steadfastly insists that the risk of over-description commits us to believing that anything only has one cause. McLachlan must only seek to simplifyeven falsify - causation if he thinks that it need always have just one basis. It might seem ridiculous to say that the cause of Princess Diana's death was her not wearing a seat-belt. But just because the causation can not be limited to this, does not mean that it ceases to be causally relevant. If it is true that she would have survived if she wore a seat-belt, it is causally important. McLachlan sees a problem-causes may be attributed to many things - and seeks to overcome it not by assessing these things but by excluding them from analysis as non-causes. This is folly. We can say that a cause of Diana's death was the lack of a seat-belt without committing ourselves to saying it was the cause. Once we start looking for the cause, we are entering the realm of fiction for the sake of argument. If we are seeking to assess the morality of a situation, the fiction is a distraction. For policy reasons, the courts may (rightly or wrongly) seek "the" cause, fictionalising the non-existence of other causes, but moral analysts have no reason to do this. Agency and its associated responsibility are what should concern us. The following bland (but not uncommon) question will help to demonstrate:

\section{"Who left the window open?"}

If the window is open, the answer to the question is everyone, but that is not the answer that is generally invited. Here are some possible (impliedly correct) answers to the question:

"The person who opened it";
"The last person who saw that it was
open";
"The person who implicitly or explicitly
took responsibility for keeping it closed."

In other words, when we ask, "Who left the window open?", we usually mean:

\section{"Who should have closed the window?"}

This question is about responsibility, not about omissions. We are not interested in an exhaustive list of people who have omitted to close the window but want to know:

\section{"Who has breached his responsibility to close this window?"}

There are many philosophical accounts that satisfactorily obviate the problem of omissions over which one has no power, such as the failure to save the lives of people whom it would be physically impossible to rescue. In assessing blameworthy omissions, Glover ${ }^{12}$ focuses on the importance of deliberation involved. Von Wright ${ }^{13}$ looks to forbearance: "Forbearance can be distinguished from mere passivity, not acting, by being intentional passivity." When we assess the morality of a measure (act or omission) that leads to a death, our concern will be the culpability of the measure, not on whether we are able to describe it as an act or an omission. So broad are the range of moral accounts that would hold this, there is an onus on commentators such as McLachlan to provide a moral framework to house their contention that every omission is morally distinct from every act. Blanket assertions that ride the back of general rules are insufficient. So are assertions based on an analyst's feeling about how things ought to be. To claim to have boiled an event down to having a single cause - and obliquely to label this "the direct cause"-is disingenuous and presupposes the lack of a need to answer questions that in fact are very much begged.

\section{CONCLUSION: PALLIATING THE CARERS}

McLachlan's commitment to whittling events down to the product of a single cause and to policing causal narratives obscures rather than assists moral argumentation and analysis. If he is correct to assert that there is a moral difference between active and passive euthanasia, he fails to demonstrate why. Furthermore, there are good reasons to doubt that he is correct. Possibly the interpretations he implies of his analogies provide a level of palliation to people involved in end-of-life care, allowing them to distance themselves from definitions such as "active euthanasia". Palliation of carers is not, however, the basis of morality. As general rules, there is good reason to support both the maxim "do not kill" and the proposition that there is no obligation to save every single person. When specific questions come to be answered-"should A kill X?"; "should B choose to do Y, knowing $Z$ will die if he does?"- the general rule is only useful in providing a rebuttable presumption. General rules do not address all specifics. Furthermore, denying the existence of necessary causes obscures matters that are relevant to moral evaluation. When considering the moral nature of an agent or his behaviour, our concern is with all he does and does not do given what he could do. To exclude what he did not do, or to subcategorise it, is not obviously helpful or right.

Acknowledgements: The author would like to thank Sheelagh McGuinness for comments on a draft of this paper and gratefully acknowledges the support of the British Academy Postdoctoral Fellowship Scheme.

\section{Competing interests: None.}

Accepted 3 March 2008

$J$ Med Ethics 2008;34:576-579.

doi:10.1136/jme.2008.024729 


\section{REFERENCES}

1. McLachlan HV. The ethics of killing and letting die: active and passive euthanasia. J Med Ethics 2008;34:636-8.

2. Keown J. Euthanasia, ethics and public policy-an argument against legalisation. Chapter 1. Cambridge: Cambridge University Press, 2002.

3. Stauch M. Causal authorship and the equality principle: a defence of the acts/omissions distinction in euthanasia. J Med Ethics 2000;26:237-41.
4. McGee A. Finding a way through the legal and ethical maze: withdrawal of medical treatment and euthanasia. Med Law Rev 2005;13:357-85.

5. Malm HM. Liberalism, bad Samaritan law, and legal paternalism. Ethics 1995;106:4-31.

6. R v Stone and Dobinson (1977) 2 WLR 169.

7. R v Gibbins and Proctor (1919) 13 Cr App R 134.

8. Airedale NHS Trust v Bland (1993) AC 789.

9. Thomson JJ. The trolley problem. Yale Law J 1985;94:1395-415.
10. Harris J. Violence and responsibility. London: Routledge and Kegan Paul, 1980.

11. Keown J. A futile defence of Bland: a reply to McGee. Med Law Rev 2005; 13:393-402.

12. Glover J. Causing death and saving lives. Chapter 7 . Harmondsworth: Penguin, 1977.

13. von Wright GH. Explanation and understanding. London: Routledge and Kegan Paul, 1971:90-1.

\section{Need a helping hand with your career choices?}

If you need to take stock, get some career advice or find out about the choices available to you then the BMJ Careers Fair is the place to do it. You can find out about how best to present yourself to potential employers, polishing up your CV, working abroad, locum working and much more.

BMJ Careers Fairs - dates for your diary

3-4 October 2008 - Business Design Centre, London

10-11 October 2008 - Thinktank, The Science Museum, Birmingham - working in partnership with the West Midlands Deanery

Register now at bmjcareersfair.com

BMJ Careers 